\title{
INTRODUCTION
}

\section{The Light of Justice}

The dawn of peace must begin with the light of justice.

-Kofi Annan

Idealists argue that international society is witnessing a profound transformation. They suggest that the rise of international criminal courts over the past half century is not only evidence of the growing power of norms concerning human rights and principles of justice, but that such institutions may usher in an entirely new era of world politics. At a ceremony marking the birth of the International Criminal Court (ICC), Hans Corell, the United Nations (UN) Undersecretary for Legal Affairs declared, "A page in the history of humankind is being turned." Although some of the hyperbole used by the court's most ardent and idealistic supporters may be salesmanship, it nonetheless suggests that there was widespread belief that the new institution represented a significant change in international politics: political and military leaders will no longer be able to victimize the innocent with impunity. They will now personally be held to account for their crimes in a court of law. Scholars have suggested that this shift toward individual accountability represents a significant transfer of authority from sovereign states to international institutions. ${ }^{2}$ More broadly, proponents have lauded the rise of 
international criminal courts as a turning point in international politics, a stunning victory of principles over the realpolitik that characterize the Westphalian era. As one scholar put it, "The creation of the ICC denotes a pivotal historical moment in the development of international society."

Scholars have used different terms to describe this transformation. For example, Gary Bass refers to a growing trend toward ideal-based legalism. ${ }^{4}$ Similarly, Kathryn Sikkink suggests that the growing legitimacy of the norm of individual criminal accountability and an increase in prosecutions based on that norm are indicative of the emergence of a "justice cascade." Along the same lines, Ben Schiff uses the metaphor of a "river of justice" to capture this sense of the inevitable shift toward a more Kantian rule-based order in international politics. He writes, "The river of justice widened from the inflow of norms as people broadened their conceptions of what it is to be human and to be civilized. They shaped their identities around consensus over an expanding set of normative conceptions. The currents included people's rights against sovereigns, the ethic of accountability, and the social responsibilities of both retributive and restorative justice." ${ }^{6}$ For many, the ICC is a high point in a long process of global transformation toward a more principled order in international society.

Advocates of this view point to several seminal moments in this process. The first was the creation of the International Military Tribunal held in Nuremberg at the end of World War II. Though the victors of war have often tried the vanquished, the Nuremberg trials were notable for at least two reasons: first, they held the perpetrators of wartime atrocities to account for their crimes; and second, they afforded defendants the rights of due process that reflected contemporary standards of jurisprudence. A second key moment came in 1993 when the United Nations Security Council (UNSC) established the International Criminal Tribunal for the Former Yugoslavia (ICTY). ${ }^{7}$ In contrast with prevailing legal norms regarding war crimes, this court affirmed the principle that international accountability was not limited only to those whose crimes are committed in the context of interstate war but applies equally in situations of intrastate conflicts. ${ }^{8}$ Moreover, it also applies to situations where the government commits atrocities against its own people. In the case of Dusko Tadic, the court defended its jurisdiction over atrocities committed during internal conflicts by ruling that "the distinction between interstate wars and civil wars is losing its value as far as human beings are concerned." 9 The ICTY ensured that those guilty of these crimes 
could no longer hide behind the shield of Westphalian sovereignty. Moreover, the arrest and trial of Serbian leader Slobodan Milosevic suggested that justice finally would be brought to the highest echelons of political power. As reflected in the headlines at the time of his arrest, world leaders hailed the arrest and trial of Milosevic as the end of a turbulent era. ${ }^{10}$ Scholars added that the arrest "was an amazing triumph for the human rights movement." ${ }^{11}$

Some critics argued that although the ICTY (and the International Criminal Tribunal for Rwanda [ICTR] that soon followed) was a significant step in the advancement of the application of international law, it still suffered from a degree of "victor's justice" because it was established by the powerful states of the UN Security Council. Thus, the creation of the International Criminal Court represents the third seminal moment in the growth of the international criminal justice regime. Under the terms of the Rome Statute, the ICC could independently investigate crimes, produce arrest warrants, and try defendants accused of the most heinous international crimes, including war crimes, crimes against humanity, genocide, and aggression. ${ }^{12}$ Moreover, in contrast to the ad hoc tribunals that preceded it, the ICC is a permanent addition to the panoply of global governance institutions. Though there was much celebration among human rights activists when the ICC became operational in July 2002, significant questions remained regarding whether the court would succeed. Though the Rome Statute was able to gain the sixty ratifications necessary to establish the court, the majority of the world's nations had not yet joined the ICC and some of the most powerful actively opposed it. $^{13}$

The fourth key stage in the process of institutionalization involved two separate events, each one signaling that the ICC has emerged as a functioning court. The first came on January 26, 2009, when the ICC opened its first case against Thomas Lubanga Dyilo, a Congolese warlord who served as leader of the Union of Congolese Patriots (UCP). In addition to committing crimes against humanity, Lubanga was accused of enlisting some thirty thousand children to serve as soldiers in the conflict. ${ }^{14}$ The second came just over a month later, on March 4, when the Office of the Prosecutor (OTP) issued an arrest warrant for Omar al-Bashir, president of Sudan. ${ }^{15}$ Bashir was accused of war crimes, crimes against humanity, and genocide in the ongoing conflict in Darfur. ${ }^{16}$ Not only was the court up and running but it clearly showed its intent to hold the most powerful perpetrators accountable 
for their crimes. ${ }^{17}$ As of 2015, the ICC has 123 states parties to the statute, is in the process of investigating crimes committed in nineteen situations around the world, and is adjudicating thirty-six active cases. ${ }^{18}$

If these events are indeed harbingers of a fundamental change in international order from one rooted in the rule of force to one rooted in the rule of law, their implications are profound and far-reaching. ${ }^{19}$ Yet this wave of optimism still faces some grim realities. On February 3, 2015, a video began circulating on the Internet. The video depicted Lt. Moaz al-Kasabeh, a Jordanian pilot captured in December 2014 by the Islamic States of Iraq and Syria (ISIS), escorted at gunpoint to a steel cage. Dressed in an orange jumpsuit, the lone man is locked in the cage then doused with liquid. Moments later his captors set Kasabeh ablaze. ${ }^{20}$ Less than two weeks later, another video emerged. The video depicts over a dozen Egyptian Coptic Christians dressed in orange jumpsuits kneeling on a Libyan beach, their hands cuffed behind them. Behind each prisoner stands an ISIS jihadist dressed in black. On cue, the prisoners are forced to the ground and beheaded en masse. $^{21}$

Proponents may attribute the continued prevalence of brutality to the fact that international justice remains a work in progress. However, these events raise significant questions regarding the notion of an unstoppable river of justice moving international society toward a fundamental transformation. It strongly suggests that while much has been written about international criminal courts, important questions remain unanswered about their origins, form, and function. This book seeks to address three questions: (1) What factors drove the creation of international criminal courts? (2) Why did they take the specific form that they did, and who either supported or opposed such institutional designs? (3) How can we account for the behavior of the International Criminal Court? The answers to these questions may not only help us better understand the factors that shaped the emergence of international criminal courts but may also suggest the broader implications of their presence in international society.

Given what is at stake for international humanitarian law, it should thus come as no surprise that international criminal tribunals have garnered so much scholarly attention in such a relatively short period of time. Most of the available literature on international criminal courts focuses on the constitutional structure of tribunals, their practice, and their jurisprudence. ${ }^{22}$ However, the questions posed here beg for the use of theoretical frameworks 
capable of identifying the most influential factors shaping outcomes. Theory prompts us to carefully define assumptions and key concepts, and to clearly articulate how these elements relate to each other. Sound theorizing requires that relevant causal mechanisms are well-specified and falsifiable, and that hypotheses generated yield unambiguous predictions. ${ }^{23}$ This book develops and employs two types of international relations (IR) theory: midlevel theory and general theory. Mid-level theory focuses on narrowly defined phenomena. ${ }^{24}$ In this case, its use is largely limited to explaining outcomes specific to international criminal courts. General theory encompasses broad classes of phenomena rather than variables specific to a narrowly defined domain. ${ }^{25}$ The advantage is that developing such theory may not only be useful to explain outcomes related to the ICC or even a group of international criminal tribunals but to other international institutions more generally.

As mentioned previously, initial theorizing about the origins and design of international criminal courts has produced an emergent conventional wisdom in the literature. ${ }^{26}$ Put simply, it explains these outcomes as primarily the product of growing human rights norms cultivated by norm entrepreneurs and unprecedented levels of grassroots civil society activism across the globe. Constructivist explanations that focus primarily on principles and norms are often presented in contrast to those that might emphasize the role of power. The predominant critique is pretty straightforward: because commitment to the Rome Statute cannot be seen as contributing to a state's material power or its strategic interests, many scholars argue that the creation of the ICC is evidence of the limits of any power-based theory. ${ }^{27}$

With regard to the question of the factors that shape the operation of the ICC, there is no well-developed theoretical literature to date. Of course, given the court's brief history of existence, it is only now that the court has established a sufficient track record on which one could begin to theorize about patterns of behavior. Given that the ICC was specifically designed to divorce power from principle by making the notion of equality under the law a cornerstone of the court, one might expect (or perhaps hope) that politics and political power would have little influence on the process of adjudication. Yet, a growing number of critics have charged that the ICC is little more than a pawn of powerful Western nations used to forward a political agenda against African nations. ${ }^{28}$ These critics point to the fact that, to date, formal investigations and trials have only been established for cases drawn 
from African nations. From this perspective, power politics largely determines outcomes related to the operation of the court.

The empirical evidence presented in this book will show that both perspectives are extreme. The role of idealpolitik in the formation and design of international criminal courts is frequently overstated, as is the argument that the function of the ICC is dominated by realpolitik. Rather, the politics of international criminal courts plays out at the intersection of power and principle. Power politics play a significantly more important role in the creation and design of international criminal courts than is generally acknowledged in the literature, yet does not dominate the behavior of the ICC as some have asserted.

This book makes two principal arguments. First, it argues that the creation and design of international criminal courts are frequently as much a product of actors' interests regarding political power and influence as they are the product of norms of justice and the power of principled ideals. ${ }^{29} \mathrm{In}$ ternational criminal courts have significant implications for state power, and preferences regarding institutional design may be strongly influenced by them. ${ }^{30}$ These, in turn, influence whether an actor will support or oppose the creation of a court based on a given design. Second, the book argues that power politics can influence the behavior of international criminal tribunals, even those designed to be the most insulated from them, as is the case with the ICC. For the ICC, this has less to do with direct coercion by member states than it does on the weakness of the new court and its dependence on state cooperation. This dependence prompts the Office of the Prosecutor to internalize the preferences of states - including nonmembers of the courtwhose cooperation is important for the court to fulfill its mission. The result is a prosecutorial strategy that takes a more pragmatic approach even as it maintains commitment to the principle of responding to the gravest violations of international humanitarian law. This book is intended to complement the existing literature by showing the interplay between power and principle in the politics of international criminal courts.

In explicating the political dynamics in which international criminal courts exist, the book does not propose a monocausal explanation of outcomes or argue for the superiority of a particular theoretical paradigm. Rather, it employs a more eclectic analytical approach. ${ }^{31}$ This analytic eclecticism is reflected in the book's structure, style, and method. First, the book examines three distinct facets in the process of institutionalization: formation, design, 
and operation. Each of these facets is unique, although there is some overlap between them. For example, support or opposition to the creation of a new court is a function of design because this enables actors to determine the relative gains and costs associated with it. ${ }^{32}$ Moreover, operation is influenced by design as well because institutional procedures are spelled out in the instruments of design. Given the high degrees of precision associated with international courts relative to other international institutions, the degree of this overlap between operation and design is likely to be more much more significant in legal institutions. ${ }^{33}$ Formation, design, and operation are each addressed independently in the book's chapters, though these overlaps are acknowledged throughout. Thus, rather than having a single theoretical argument that is tested across a set of empirical chapters to follow, the book offers unique theoretical frameworks specific to each facet. Moreover, because each facet of institutionalization has generated its own specific literature, these are reviewed separately in each chapter rather than collectively in a single literature review chapter as is common in social science research. The second type of eclecticism reflected in the book involves epistemological style. The theoretical frameworks offered to explain outcomes all share a common emphasis on the role of power politics, but do so by combining specific elements drawn from the realist tradition in IR with other new or existing theoretical approaches. ${ }^{34}$ These include regime complex theory and two-level game frameworks, as well as a new theory of internalization applied to the calculation of egoistic institutional interests. Lastly, the book's analytical approach is also eclectic with regard to method. Rather than employing one method of analysis, the book employs both quantitative and qualitative approaches at multiple levels of analysis. These include historical process tracing, textual analysis, nonlinear regression analysis, and event history regression analysis. Data used in these analyses are drawn from the creation of several original data sets, archival records, elite interviews, as well as an array of secondary sources.

The book is structured as follows. Chapter 1 presents a historiography of the period from 1945 to 1994 to explore the factors that affected the timing and shape of ad hoc international criminal tribunals. Much of the existing scholarship on the creation of these courts points to legal principles and norms as the primary reasons such courts came into being. In contrast to this prevailing view, this chapter shows how different elements of realpolitik motivated their creation. Once the decision to create a court was made, however, 
norm entrepreneurs had an opportunity to shape these institutions in ways that forwarded key principles of evolving international humanitarian law. The chapter begins by examining the creation of the International Military Tribunal (IMT) held in Nuremberg, Germany and the International Military Tribunal for the Far East (IMTFE) held in Tokyo, Japan at the close of World War II. The historical evidence makes clear that when considering options for dealing with their enemies at the end of the war, the Allied powers emphasized the role the tribunals could play in determining whether the Axis powers waged a war of aggression. Though the popular contemporary narrative regarding the IMT is that it was primarily a response to the horrors of the Holocaust and the crimes against humanity committed by the Nazis, the evidence suggests that this was not the initial rationale for creating the court. In short, the court's initial purpose from the point of view of the Allied leadership was to prosecute the jus ad bellum (the right to war). ${ }^{35}$ Unpacking this crucial distinction between the jus ad bellum and the jus in bello (war crimes) enables one to see that the IMT was the product the intersection between realpolitik and idealpolitik because it involves legitimizing the use of force in war. Once the decision to establish the court was made, norm entrepreneurs then shaped its jurisprudence, and ultimately, its legacy.

Chapter 1 goes on to show not only how Cold War realpolitik served to impair further development of an international atrocities regime for decades but also how interests in the form of power intersected with human rights principles to shape their reemergence on the international landscape in the early 1990s. Some scholars have suggested that domestic outcry over atrocities committed in the Balkans and Rwanda prompted the UN Security Council to create the ICTY and ICTR. Yet the empirical evidence only partially validates this view. Chapter 1 suggests that for liberal democratic members of the UN Security Council that created the tribunal, creating the ad hoc courts was a way to respond to these crises in a way that involved lower cost and less political risk than more assertive policy options-particularly military intervention. For illiberal members of the Security Council, the decision to support (or simply not veto) these courts was a tactical decision rooted in a broader grand strategy predicated on forging closer relations with the United States and members of the European Community. As was the case with the IMT, once created, these ad hoc tribunals served as a vehicle 
for norm entrepreneurs to further develop the tribunal regime in ways consistent with evolving notions of international human rights law. By systematically analyzing the ad hoc courts from Nuremberg to The Hague, chapter 1 shows how power and principle intertwined to forge the growing ad hoc tribunal regime.

Chapter 2 examines the creation of the International Criminal Court, emphasizing the politics of institutional design. Much of the current literature on the creation of the ICC argues that support or opposition to the court can be largely explained in terms of growing support for principles of international humanitarian law. This offers a parsimonious but overly simplified account of the politics surrounding the formation and design of the ICC. In contrast, chapter 2 shows that for many states, interests regarding human rights were not necessarily their only concern during the Rome Conference. For a number of states participating in the negotiations, interests were at least partially defined in terms of power, and these strongly shaped their preferences regarding the institutional design of the ICC. These power considerations were far from marginal. In fact, they brought to bear questions regarding the architecture of international order and its institutionalized hierarchies. During the Rome Conference negotiations, a battle was waged between states seeking to maintain their relative position in the global hierarchy and those attempting to restructure that hierarchy in part by creating a specific type of international criminal court. This struggle was waged by several of the world's most powerful states and a coalition of "dissatisfied powers" engaged in a broader struggle to close the gap between the privileged and the marginalized in international society.

Chapter 2 explicates these dynamics by integrating two different strands of theoretical research. It combines insights from research that illustrate how power is vested in the creation and design of international institutions, with insights from the literature on regime complexes. ${ }^{36}$ Synthesizing these frameworks shows how state power can be affected by relationships between institutions. This new theoretical framework is then used to explain state interests regarding a subset of Rome Conference participants and why the issue of Security Council control was so central to the negotiations regarding the design of the ICC. This political struggle centered on the question of whether the ICC would be nested within the UN/UNSC or would be designed independent of it. Using a combination of quantitative and qualitative methods 
of analysis, the chapter explicates the process of institutional design. This includes the PrepCom meetings (1996-98), the Rome Conference (1998), and the Kampala Review Conference (2010).

Although the empirical evidence presented in chapter 2 supports the hypotheses regarding the role of interests defined in terms of power in shaping the design of the court and who ultimately supported or opposed it, it also reveals several key outliers whose behavior seems at odds with what the structurally based theory predicted. Why was Guatemala the lone defector among the dissatisfied powers? Moreover, why did Britain and France both defect from the P5 consensus that sought a court largely controlled by the Security Council? Chapter 3 draws on Robert Putnam's two-level game framework to generate expectations regarding state preferences for each of the outliers. ${ }^{37}$

Scholars have suggested that domestic politics played an important role in explaining the shift in the British position vis-à-vis the Rome Statute and argue that this was a product of changing British values. ${ }^{38}$ From this perspective, the rise of New Labour's "ethical foreign policy" in 1997 signaled a responsiveness to changing public attitudes in Britain that increasingly value humanitarian principles in the determination of foreign policy interests. The evidence presented in chapter 3 shows that this was not necessarily the case. It explains the British shift as a function of New Labour's electoral tactics created as part of a broad strategy to unseat the Conservative government and assume control over the government. Moreover, the evidence presented in chapter 3 shows that this use of principled rhetoric did not signal a fundamental shift in British attitudes, but rather, was a relatively short-term political tactic that was later discarded by those who employed it during the 1997 election. Chapter 3 goes on to explain how the change in the British position altered France's win set with regards to the Rome Statute. France was among the most ardent supporters of a weaker ICC with extremely limited powers to act independently. Like the British, French design preferences regarding the ICC were influenced by interests defined in terms of power, but at multiple levels. For the French, this was not a product of domestic politics, but rather, intra-European Union (EU) political interests. As soon as Britain changed positions, France faced the prospect of emerging from the conference as the lone holdout against the Rome Statute design among EU nations. Yet, even late in the game France was reluctant to budge. Ultimately, eleventh-hour design concessions offered by the Like-Minded 
Group (LMG) served to bridge the gap with French preferences regarding the statute.

Unlike the cases of Britain and France, Guatemala's behavior regarding the design of the ICC has not garnered scholarly attention. Instead, the literature largely focuses on the Like-Minded Group, reflecting perhaps an assumption among scholars that this group represented largely homogeneous interests regarding institutional design. Like the other two outliers examined here, domestic politics are equally important to explain Guatemala's behavior regarding the ICC. In this case, reluctance to join the LMG in favor of a strong and independent court was a product of individual and party survival. The chapter explores the history of crimes committed during the reign of Efraín Ríos Montt and explains how his vulnerability to international prosecution pushed his Frente Republicano Guatemalteco party and their political allies to oppose the ICC. Once domestic political conditions changed in Guatemala, the government changed its position and has now joined the court. ${ }^{39}$

Chapter 4 goes on to show how the intersection of power and principle affects the operation of the International Criminal Court. Why does the ICC pursue some cases but not others? Moreover, why does it move the process of adjudication more rapidly for some situations and more slowly for others? The Office of the Prosecutor maintains that prosecutorial choices are made solely in accordance with accepted norms of jurisprudence. ${ }^{40}$ Chief Prosecutor Fatou Bensouda stated emphatically that "we are a new tool, a judicial tool, not a tool in the hands of politicians who think they can decide when to plug or unplug us." 41 A growing number of critics have argued that the court is little more than a tool of powerful Western states utilized primarily to forward an anti-Africa agenda. ${ }^{42}$ Is prosecutorial strategy driven primarily by issues of jurisprudence or politics? Though legal factors alone cannot account for the many inconsistencies evident on the court's docket, the empirical evidence does not support the notion that the ICC is the victim of "institutional capture" by powerful states. ${ }^{43}$ Chapter 4 forwards a theory of prosecutorial strategy that explains why egoistic institutional interests may internalize the preferences of external actors. In particular, this theoretical framework provides a rationale for why the strategic interests of three of the most powerful nonmember states may be internalized by the OTP. Using a mixed-methods approach that draws on an original data set of legal and political variables, Chapter 4 shows how prosecutorial strategy emerges from 
the intersection of principle, power, and pragmatism. While international legal principles press the OTP to place greater emphasis on situations deemed to be the most grave, institutional pragmatism prompts the court to move much more cautiously in cases involving the strategic interests of three important nonmember states - the United States, Russia, and China.

At the time he took office, the chief prosecutor considered support from the permanent members of the UN Security Council to be "crucial" to its long-term mission. ${ }^{44}$ The Security Council solely possesses the authority to sanction coercive military intervention to intervene in situations where grave violations of international humanitarian law are taking place. The Security Council is also the only body with the power to grant the ICC jurisdiction over situations involving the actions of nonmember states. As such, it alone holds the key to extending the jurisdictional reach of the court where doing so is necessary if perpetrators of mass atrocities are to be held accountable for their crimes. Moreover, the ability of the ICC to respond to humanitarian crises would be severely hampered should the permanent members of the Security Council seek to actively obstruct the court. Two permanent members of the Security Council, Britain and France, are members of the ICC and have offered consistent support to the court. With their support already in hand, it is rational for the OTP to pursue an institutional course aimed partially at forging better relations with the three remaining permanent members of the Security Council that are not members of the court: the United States, Russia, and China. Thus, it is in the egoistic institutional interests of the ICC to carefully consider the interests and potential reaction of these three countries as it considers is prosecutorial strategy. In other words, it is rational to expect that these interests may be internalized in the process of defining the institutional interests of the ICC. This internalization does not dictate that the prosecutorial strategy of the OTP is primarily driven by deference to American, Russian, or Chinese interests. Rather, this chapter suggests that these internalized interests may serve as a significant intervening variable in the process of adjudication. The findings presented in chapter 4 have significant normative implications. Although idealists are reluctant to sacrifice principle in the face of power, the realization of the court's important long-term goals relies on integrating power and principle through pragmatism.

The concluding chapter provides a brief overview of the key findings presented in the book, highlighting the argument that beneath the discourse 
regarding rights and justice that surround international criminal courts is a complex system of global power politics. As shown in the chapters that precede it, realpolitik and idealpolitik intertwine to shape the creation, design, and operation of international criminal courts. In addition to providing a brief summary of the book's major findings and their significance to scholarship on international criminal courts and international politics more generally, the concluding chapter returns to a basic question raised throughout the book: Does the creation of the ICC signal a transformation of international society? Proponents of the ICC have suggested that the adoption of the Rome Statute signaled a revolutionary shift in world order away from the realpolitik of the Westphalian system toward a more Kantian model, one based on core principles and the rule of law. A better understanding the role that power politics has played in the development of the atrocities regime prompts a more measured assessment of the impact international criminal courts have had on world order.

Do international criminal courts deter the commission of atrocities? Though it is certainly difficult to assess deterrence in any context, the anecdotal evidence is not compelling. The deterrent effect of potential tribunal action has done little to stem the commission of atrocities in places such as North Korea, Syria, Mali, and the Central African Republic. Moreover, the recurring violence in Mali and the Central African Republic even after the ICC has begun adjudicating those situations suggests that deterrence is elusive. In spite of that, the book does not suggest that international criminal courts are simply tools of powerful states as some critics of the ICC have argued. Nor does it suggest that international criminal courts will not contribute to global peace and the protection of human rights. Rather, international justice alone is not sufficient to realize these lofty goals - it requires the support of powerful states. Thus, principles of justice may need to heed the realities of international power politics by adopting a more pragmatic approach. International criminal courts have facilitated the articulation and diffusion of norms of human rights and individual accountability for conduct during conflict, both domestic and international. But the contemporary international order is based on another core principle: great power prerogative and special responsibilities. ${ }^{45}$ Rather than attempt to supplant this principle of international order with one based on equality under the law, the ICC may find it necessary to accept some degree of great power exceptionalism in 
exchange for great power support so essential to a functioning legal institution. It seems that the OTP already has adopted this stance de facto, but is certainly not inclined to acknowledge it publicly. Although this has generated some criticism among human rights advocates, this course may be the most appropriate if international justice is to contribute to global peace and stability in the long run. Already, the United States has softened its stance against the ICC, and it is not inconceivable that it might someday join the court. China and Russia may be more reluctant partners, but they too have shown a more positive view so long as the court action conforms to current norms regarding Security Council control over issues of international peace. In short, the struggle between power and principle need not be decided wholly in favor of one over the other. 